\title{
In-vitro evaluation of bactericidal activity of antiseptics and disinfectants commonly used in healthcare settings
}

\author{
Perera KC ${ }^{1}$, Ekanayaka SK ${ }^{1}$, Chandrasiri NS ${ }^{2}$, Jayatilleke K ${ }^{3}$, Kottahachchi $\mathbf{J}^{1}$, \\ ${ }^{\prime}$ Faculty of Medical Sciences, Department of Microbiology, University of Sri Jayewardenepura, Gangodawila, \\ Nugegoda, Sri Lanka, \\ ${ }^{2}$ Department of Microbiology, Colombo South Teaching Hospital, Kalubowila, Sri Lanka, \\ ${ }^{3}$ Department of Microbiology, Sri Jayewardenepura General Hospital, Thalapathpitiya, \\ Nugegoda, Sri Lanka. \\ Correspondence: Mr. K. C.Perera \\ e-mail: science286@gmail.com \\ (D) https://orcid.org/0000-0002-0968-2728 \\ Submitted on 21.01.2021 and accepted for publication on 28.03.2021
}

\begin{abstract}
Introduction: Healthcare-associated infections are common problems found in healthcare systems in most of the countries. Proper use of antiseptics and disinfectants is useful in reducing the magnitude of such infections. The aim of this study was to evaluate the bactericidal effect of different concentrations of selected antiseptics and disinfectants.
\end{abstract}

Methods: Bactericidal activity of different concentrations of antiseptics and disinfectants; isopropyl alcohol, povidone iodine, chlorhexidine gluconate, sodium hypochlorite, hypertonic saline, peracetic acid and mixture of 2-aminoethanol, dodecyl dimethyl ammonium chloride, potassium carbonate \& bis(3-aminopropyl) dodecylamine were evaluated against nine strains of American Type Culture Collections and 11 strains isolated from the hospitals. Bacterial suspensions were prepared equal to $0.5 \mathrm{McFarland}$ turbidity standards and $100 \mu \mathrm{l}$ of each was mixed with $3 \mathrm{ml}$ of antiseptic/ disinfectant solution. After desired contact time (1 minute, 15 minutes and 24 hours), $20 \mu \mathrm{l}$ of reaction mixer was transferred into $4 \mathrm{ml}$ of sterile physiological saline, mixed well and $20 \mu 1$ of solution was evenly spread throughout Muller Hinton agar/ blood agar plates. Growth control was done using $3 \mathrm{ml}$ of distilled water instead of $3 \mathrm{ml}$ of antiseptic/ disinfectant solution. All plates incubated at $35^{\circ} \mathrm{C} \pm 2^{\circ} \mathrm{C}$ for $18-24$ hours. Colonies were counted and reduction percentage was calculated.

Results: All concentrations of isopropyl alcohol, povidone iodine, chorhexidine, sodium hypochlorite, peracetic acid and the mixture of 2-aminoethanol, didecyldimethylammonium chloride, potassium carbonate and bis(3-aminopropyl)dodecylamine showed $100 \%$ bactericidal activities against all tested bacterial strains in 1-minute contact time. Bactericidal activity of hypertonic saline was varied against tested bacterial strains with higher bactericidal activity against Gram positive organisms than Gram negative organisms.

Conclusions: Currently using concentrations of antiseptics and disinfectants evaluated in this study have $100 \%$ bactericidal activity other than hypertonic saline.

Key words: Antiseptics, bactericidal activity, disinfectants, healthcare associated infections. 


\section{Introduction}

Healthcare-associated infections (HAIs) and polymicrobial wound infections found in chronic wounds are common problems encountered in healthcare systems in most of the countries including Sri Lanka.

These infections have been recognised as a critical problem affecting the quality of health care settings over a century (1). HAIs cause to increase length of hospital stay, permanent disability and patient mortality. Infection rate ranges from one in five admissions in some developing countries to one in twenty admissions in developed countries (2). Escherichia coli, Staphylococcus aureus, Enterococcus faecium, Acinetobacter baumannii cause most of the multidrug resistant HAIs (3). Extended Spectrum Beta-Lactamase (ESBL) producing organisms are the challenge to healthcare practice around the world. On the other hand, polymicrobial infections in chronic wounds are another problem identified in healthcare systems. Polymicrobial infections can be identified in these wounds where Gram positive bacteria have become predominant than Gram negative bacteria. Staphylococcus spp., Enterococcus spp. and Streptococcus spp. are found as common Gram positive bacteria, out of which $S$. aureus has been reported as the most frequently isolated spp., whereas Pseudomonas spp. are the most common among the Gram negative bacteria $(4,5)$.

Antiseptics and disinfectants are used to curtail the healthcare associated infections. Different types of antiseptics and disinfectants are used in healthcare settings in Sri Lanka including alcohols, iodophores, chlorhexidines, chlorine releasing agents, peracetic acids. Therefore, this study was planned to determine the bactericidal effect of different concentrations of selected antiseptics and disinfectants.

\section{Methods \\ Test Strains}

Nine strains of American Type Culture Collections (ATCC) were used. Namely Methicillin-sensitive Staphylococcus aureus (MSSA) ATCC 25923, Methicillin-resistant Staphylococcus aureus (MRSA) ATCC 43300, Streptococcus pyogenes ATCC12384, Enterococcus faecalis ATCC 29212, Acinetobacter baumannii ATCC 19606, Escherichia coli (Non ESBL) ATCC 25922, Klebsiella pneumoniae (ESBL) ATCC 700603, Klebsiella pneumoniae (Carbapenem resistance) ATCC BAA1705 and Pseudomonas aeruginosa ATCC 27853.

Eleven clinical isolates used in this study were as follows; Staphylococcus aureus (MSSA), Staphylococcus aureus (MRSA), Enterococcus spp., Group A Streptococci, Group B Streptococci, Acinetobacter spp., Escherichia coli (Non ESBL), Escherichia coli (ESBL), Klebsiella spp., Klebsiella spp., (Carbapenem resistant), Pseudomonas spp.

\section{Test method}

Different concentrations of selected antiseptics and disinfectants were prepared in laboratory using commercially available concentrations of each antiseptic and disinfectant. All concentrations are shown in Table 1.

Table 1: Concentrations of antiseptics / disinfectants

\begin{tabular}{|c|c|c|c|c|}
\hline \multirow[t]{2}{*}{ Antiseptics / Disinfectants } & \multicolumn{4}{|c|}{ Concentration (v / v ) } \\
\hline & Lower 2 & Lower 1 & Already used & Higher \\
\hline Isopropyl alcohol & $40 \%$ & $50 \%$ & $60 \%$ & - \\
\hline Povidone iodine & $1 \%$ & $5 \%$ & $10 \%$ & - \\
\hline Chlorhexidine gluconate & $1 \%$ & $2 \%$ & $4 \%$ & - \\
\hline Sodium hypochlorite & $0.1 \%$ & $0.5 \%$ & $1 \%$ & - \\
\hline Peracetic acid & $1.22 \%$ & $1.42 \%$ & $1.62 \%$ & - \\
\hline $\begin{array}{l}\text { Mixture of [2-aminoethanol, } \\
\text { didecyldimethylammonium chloride, potassium } \\
\text { carbonate, bis(3-Aminopropyl) dodecylamine] }\end{array}$ & $1.5 \%$ & $2 \%$ & $2.5 \%$ & - \\
\hline Hypertonic saline & - & - & $1.9 \%$ & $2.9 \%$ \\
\hline
\end{tabular}


Following preparation of antiseptic and disinfectant solutions, test bacterial suspensions of each organisms were prepared equal to $0.5 \mathrm{McFarland}$ turbidity standards (6). After preparing antiseptic and disinfectant solutions and test suspensions, $3 \mathrm{ml}$ of different concentrations of antiseptic or disinfectant solutions were added into clean sterile bijou bottles. Afterwards, $100 \mu 1$ of each bacterial suspension prepared was added into sterile bijou bottles separately containing tested concentration of antiseptics or disinfectants and thoroughly mixed using vortex mixer. After 1 minute contact time, $20 \mu \mathrm{l}$ of aliquot was separated as soon as possible and was added into sterile bijou bottle containing $4 \mathrm{ml}$ of sterile physiological saline. Following mixing of the contents thoroughly, $20 \mu \mathrm{l}$ of solution was transferred on to Muller Hinton agar (MHA) plates and spread evenly throughout the plate using a sterile glass spreader. Blood agar plates were used for Streptococcus species instead of Muller Hinton agar plates. The plates were incubated at $35^{\circ} \mathrm{C} \pm 2^{\circ} \mathrm{C}$ for $18-24$ hours. Thereafter 15 minutes and 24 hours contact time were achieved; same procedure mentioned above was followed. Yielded colonies were counted and reduction percentage was calculated (7-10).
Test control procedure was done as follows. Three milliliters of distilled water was added into clean sterile bijou bottle followed by $100 \mu$ l of bacterial suspension and thoroughly mixed using vortex mixer. From the above mixture, $20 \mu 1$ was added into bijou bottles containing $4 \mathrm{ml}$ of sterile physiological saline and mixed thoroughly. Muller Hinton agar plates were added $20 \mu 1$ of mixed solution and spread evenly. Blood agar was used for Streptococcus species instead of MHA. The plates were incubated at $35^{\circ} \mathrm{C} \pm 2^{\circ} \mathrm{C}$ for $18-24$ hours and colonies were counted. Test and control procedures were duplicated.

Reagent control was done by adding $3 \mathrm{ml}$ of distilled water into clean sterile bijou bottles followed by mixing $100 \mu \mathrm{l}$ of sterile physiological saline instead of bacterial suspension into bijou bottles containing distilled water. The same procedure as above was practiced thereafter. Sterility of MHA and blood agar plates were tested after incubating without spreading any solution.

All evaluated concentrations of antiseptics and disinfectants except hypertonic saline showed 100\% bactericidal activity (Table 2) against all the standard strains and clinical isolates. Bactericidal activity of hypertonic saline was varied (Table 3 and Table 4). However it is more effective against Gram positive bacteria than Gram negative bacteria.

Table 2: Bactericidal activity of all tested concentrations of isopropyl alcohol, povidone iodine, chlorhexidine gluconate, sodium hypochlorite, peracetic acid and the mixture of 2-aminoethanol, didecyldimethylammonium chloride, potassium carbonate, bis(3-aminopropyl) dodecylamine

\begin{tabular}{lcc}
\hline Antiseptic / Disinfectant & $\begin{array}{l}\text { Bactericidal activity against } \\
\text { standard strains (1 min/ } \\
\mathbf{1 5} \text { mins/ 24 hrs ) }\end{array}$ & $\begin{array}{l}\text { Bactericidal activity } \\
\text { against clinical isolates } \\
\text { (1 min/ 15 mins/ 24 hrs) }\end{array}$ \\
\hline $\begin{array}{l}\text { Isopropyl alcohol } \\
(40 \% \text { / 50\% / 60\%) }\end{array}$ & $100 \%$ & $100 \%$ \\
\hline $\begin{array}{l}\text { Povidone iodine } \\
(1 \% \text { / 5\% / 10\% ) }\end{array}$ & $100 \%$ & $100 \%$ \\
\hline $\begin{array}{l}\text { Chlorhexidine gluconate } \\
(1 \% \text { / 2\% / 4\% ) }\end{array}$ & $100 \%$ & $100 \%$ \\
\hline $\begin{array}{l}\text { Sodium hypochlorite } \\
(0.1 \% \text { / 0.5\% / 1\% ) }\end{array}$ & $100 \%$ & $100 \%$ \\
\hline $\begin{array}{l}\text { Mixture of 2-aminoethanol, } \\
\text { didecyldimethylammonium } \\
\text { chloride, potassium carbonate, } \\
\text { bis(3-aminopropyl)dodecylamine } \\
(1.5 \% \text { / 2\% / 2.5\% ) }\end{array}$ & $100 \%$ & $100 \%$ \\
\hline $\begin{array}{l}\text { Peracetic acid } \\
(1.22 \% \text { / 1.42\% / 1.62\% ) }\end{array}$ & & \\
\hline
\end{tabular}


After 24 hours contact time with 1.9\% hypertonic saline, all Gram-positive organisms except Enterococcus faecalis (ATCC 29212), showed over ninety percent bacterial reductions. Further, all Gram positive organisms except Enterococcus faecalis (ATCC 29212) showed 100\% bacterial reductions against $2.9 \%$ hypertonic saline.

Of Gram-negative organisms, Acinetobacter baumannii (ATCC 19606) showed 67.48\% and $68.20 \%$ bacterial reduction against $1.9 \%$ hypertonic saline and $2.9 \%$ hypertonic saline respectively for 24 hours of contact time. However, other Gramnegative organisms did not show a prominent bacterial reduction against either $1.9 \%$ or $2.9 \%$ hypertonic saline (Table 3 ).

As far as the clinical isolates are concerned, all Gram-positive isolates except Enterococcus spp. showed over $80 \%$ reduction after 24 hours contact time for $1.9 \%$ hypertonic saline and $100 \%$ reduction after 24 hours contact time for $2.9 \%$ hypertonic saline. None of the Gram-negative isolates showed $100 \%$ reduction for either of the tested concentrations of hypertonic saline at any contact time. The best reduction was recorded in Acinetobacter spp. where it shows $66.27 \%$ after 24 hours of contact time for $2.9 \%$ hypertonic saline (Table 4).

Figure 1 shows control growth of the streptococcus pyogenes (ATCC 12384) on blood agar plates after 18-24 hours of incubation. Figures 2, 3 and 4 show test growth of streptococcus pyogenes (ATCC 12384 ) against $1.9 \%$ hypertonic saline after 1 minute, 15 minutes and 24 hours respectively. Figure 5, 6 and 7 show test growth of streptococcus pyogenes (ATCC 12384) after 1minute, 15 minutes and 24 hours respectively against $2.9 \%$ hypertonic saline.

Table 3: Bactericidal activity of hypertonic saline against American Type Culture Collection strains

\begin{tabular}{|c|c|c|c|c|c|c|}
\hline \multirow[t]{2}{*}{ Name of organisms } & \multicolumn{3}{|c|}{ 1.9\% Sodium chloride } & \multicolumn{3}{|c|}{ 2.9\% Sodium chloride } \\
\hline & $1 \mathrm{~min}$ & $15 \min$ & 24 hours & $1 \mathrm{~min}$ & $15 \mathrm{~min}$ & 24 hours \\
\hline \multicolumn{7}{|l|}{ Gram positive organisms } \\
\hline $\begin{array}{l}\text { Streptococcus pyogenes } \\
\text { ATCC } 12384\end{array}$ & 6.42 & 7.71 & 92.11 & 8.07 & 20.55 & 100.00 \\
\hline $\begin{array}{l}\text { Enterococcus faecalis } \\
\text { ATCC } 29212\end{array}$ & 1.49 & 2.13 & 21.70 & 2.13 & 6.38 & 22.13 \\
\hline $\begin{array}{l}\text { Staphylococcus aureus (MSSA) } \\
\text { ATCC } 25923\end{array}$ & 5.80 & 36.81 & 99.71 & 8.70 & 39.71 & 100.00 \\
\hline $\begin{array}{l}\text { Staphylococcus aureus (MRSA) } \\
\text { ATCC } 433000\end{array}$ & 4.32 & 24.16 & 99.72 & 5.62 & 30.90 & 100.00 \\
\hline \multicolumn{7}{|l|}{ Gram negative organisms } \\
\hline $\begin{array}{l}\text { Acinetobacter baumannii } \\
\text { ATCC } 19606\end{array}$ & 0.97 & 0.73 & 67.48 & 0.97 & 9.47 & 68.20 \\
\hline $\begin{array}{l}\text { Escherichia coli (Non ESBL) } \\
\text { ATCC } 25922\end{array}$ & 0.00 & 0.53 & 4.52 & 3.46 & 3.99 & 7.45 \\
\hline $\begin{array}{l}\text { Klebsiella pneumoniae (ESBL) } \\
\text { ATCC } 700603\end{array}$ & 0.54 & 1.08 & 2.97 & 3.24 & 3.78 & 9.19 \\
\hline $\begin{array}{l}\text { Klebsiella pneumoniae } \\
\text { (carbapenem resistant) ATCC } \\
\text { BAA1705 }\end{array}$ & 0.00 & 0.59 & 3.85 & 2.07 & 0.89 & 5.03 \\
\hline $\begin{array}{l}\text { Pseudomonas aeruginosa } \\
\text { ATCC } 27853\end{array}$ & 0.27 & 0.54 & 1.34 & 5.36 & 8.31 & 9.92 \\
\hline
\end{tabular}




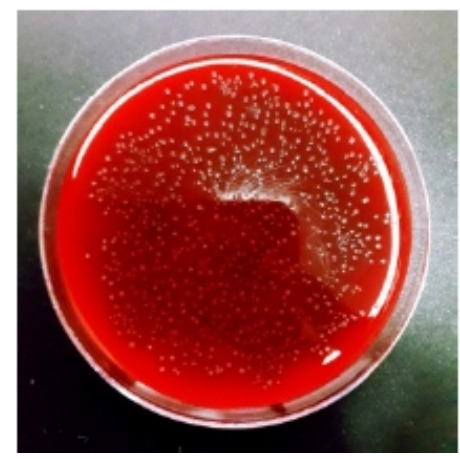

Figure 1: Streptococcus pyogenes (ATCC 12384) Test Control growth

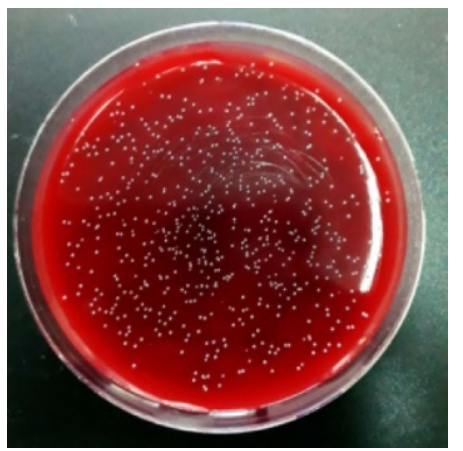

Figure 2: Streptococcus pyogenes (ATCC 12384) After 1 minute contact time against $1.9 \%$ hypertonic saline

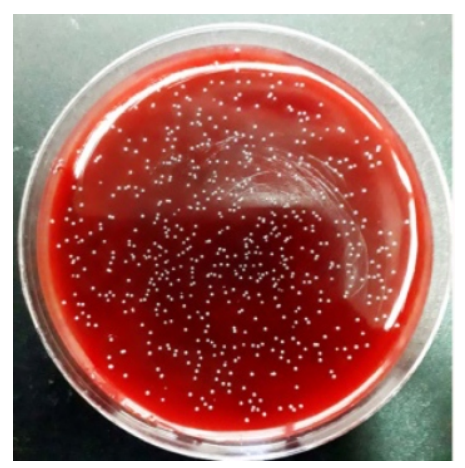

Figure 3: Streptococcus pyogenes (ATCC 12384) After 15 minutes contact time against $1.9 \%$ hypertonic saline

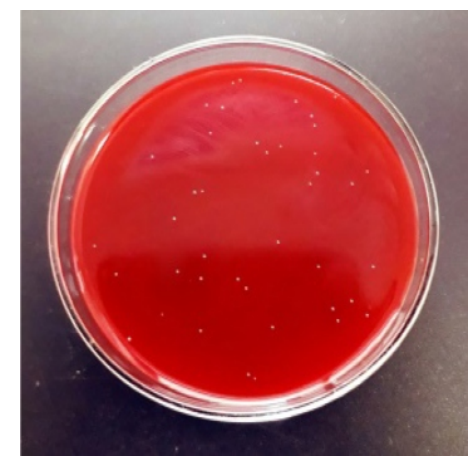

Figure 4: Streptococcus pyogenes (ATCC 12384) After 24 hours contact time against $1.9 \%$ hypertonic saline

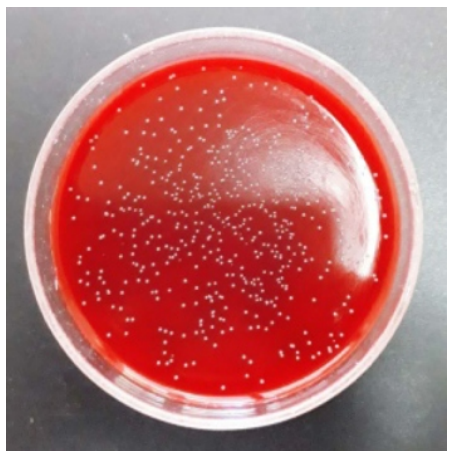

Figure 5: Streptococcus pyogenes (ATCC 12384) After 1 minute contact time against $2.9 \%$ hypertonic saline

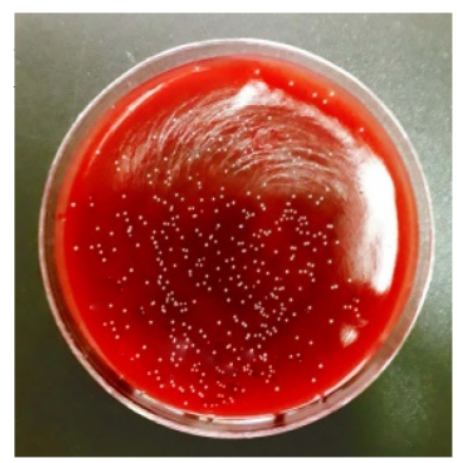

Figure 6: Streptococcus pyogenes (ATCC 12384) After 15 minutes contact time against $2.9 \%$ hypertonic saline

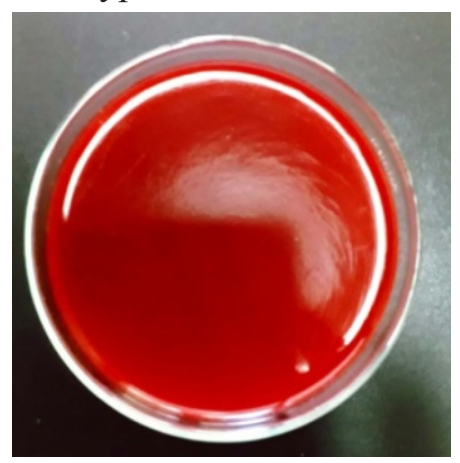

Figure 7: Streptococcus pyogenes (ATCC 12384) After 24 hours contact time against $2.9 \%$ hypertonic saline 
Table 4: Bactericidal activity of hypertonic saline against clinical isolates

\begin{tabular}{|c|c|c|c|c|c|c|}
\hline \multirow[t]{2}{*}{ Name of Organisms } & \multicolumn{3}{|c|}{ 1.9\% Sodium chloride } & \multicolumn{3}{|c|}{$2.9 \%$ Sodium chloride } \\
\hline & $1 \mathrm{~min}$ & $15 \mathrm{~min}$ & 24 hours & $1 \mathrm{~min}$ & $15 \mathrm{~min}$ & 24 hours \\
\hline \multicolumn{7}{|l|}{ Gram positive organisms } \\
\hline Group A Streptococcus & 4.74 & 7.3 & 87.77 & 7.30 & 13.87 & 100.00 \\
\hline Group B Streptococcus & 1.01 & 4.64 & 86.90 & 3.02 & 18.75 & 100.00 \\
\hline Enterococcus spp. & 2.87 & 5.50 & 26.32 & 4.07 & 8.13 & 32.54 \\
\hline Staphylococcus aureus (MSSA) & 0.91 & 14.81 & 99.54 & 5.01 & 22.55 & 100.00 \\
\hline Staphylococcus aureus (MRSA) & 0.00 & 7.87 & 99.31 & 3.47 & 10.42 & 100.00 \\
\hline \multicolumn{7}{|l|}{ Gram negative organisms } \\
\hline Acinetobacter spp. & 2.89 & 5.78 & 63.61 & 1.69 & 7.71 & 66.27 \\
\hline Escherichia coli (Non ESBL) & 2.17 & 5.26 & 13.93 & 3.10 & 8.05 & 21.36 \\
\hline Escherichia coli (ESBL) & 2.03 & 3.77 & 6.38 & 2.90 & 4.35 & 14.2 \\
\hline Klebsiella spp. & 3.43 & 5.58 & 18.03 & 3.43 & 7.73 & 21.89 \\
\hline $\begin{array}{l}\text { Klebsiella spp. (carbapenem } \\
\text { resistant) }\end{array}$ & 0.83 & 4.13 & 22.31 & 5.79 & 14.46 & 33.88 \\
\hline Pseudomonas spp. & 2.38 & 5.56 & 15.34 & 2.12 & 7.94 & 16.67 \\
\hline
\end{tabular}

\section{Discussion}

Present study evaluates the bactericidal activity of commonly used antiseptics and disinfectants and hypertonic saline against ATCC strains and clinical isolates. Different concentrations of antiseptics/ disinfectants have been used in this study; the currently used concentration and two lower concentrations in case of antiseptics/ disinfectants and a higher concentration in case of hypertonic saline.

Isopropyl alcohol is used to disinfect skin and for cleaning of surfaces in healthcare setting along with general purpose detergents. Ten percent povidone iodine is used to disinfect skin and used as active wound dressings (11).

Chlorhexidine is commonly used in antiseptic products such as handwashes and mouth washes (12) and 4\% solution is used for skin preparation (11). In a previous study, Sassone et al., showed that $0.12 \%$ chorhexidine solution cannot eliminate Enterococcus faecalis at any time tested which is immediately, after 5 minutes, 15 minutes and 30 minutes of contact. However, 1\% chorhexidine could eliminate the E. faecalis after immediate contact (8). Vianna et al reported $100 \%$ bactericidal effect of $1 \%$ chlohexidine after 15 seconds contact time against $S$. aureus and E. faecalis (7). Current study illustrated $100 \%$ bactericidal activity of the solution in all tested contact durations, 1 minute, 15 minutes and 24 hours.

One percent sodium hypochlorite is used to disinfect spills of body fluid and blood and $0.1 \%$ is used as an environmental disinfectant (11). Sassone, et al., had shown that $1 \%$ sodium hypochlorite can eliminate bacterial growth of E. faecalis, E. coli, S. aureus, etc after immediate contact (8). Similarly, the current study reported bactericidal activity of the compound in all concentrations and contact durations.

Endoscopes are used as a diagnostic and therapeutic tool in medical practice. These instruments do not withstand heat and recommended reprocessing method is use of high level disinfectants such as gluteraldehyde containing chemicals (13). 
Considering the probable adverse effect of to healthcare staff, glutaraldehyde free high level disinfectants such as peracetic acid, are used for reprocessing of endoscopes (11). Therefore, bactericidal activity of peracetic acid and the mixture of 2-aminoethanol, didecyldimethylammonium chloride, potassium carbonate \& bis(3-aminopropyl) dodecylamine is used in healthcare settings were evaluated in the current study. Similar to previously mentioned solutions, these chemicals too showed $100 \%$ bactericidal activity. In a previous study, Baldry had determined antimicrobial activity of different concentrations of peracetic acid and they had obtained $10^{6}$ factor reduction against $1.3 \mathrm{mmol} / \mathrm{L}$ of peracetic acid within 1 minute (14).

Hypertonic saline is also used to treat wounds with the concentration of $1.9 \%$. According to results of present study, hypertonic saline is more effective to Gram positive organisms than Gram negative organisms. Michon et al. had evaluated bactericidal activity of different concentrations of sodium chloride $(\mathrm{NaCl})$. They had shown that all of the Pseudomonas species tested have been inhibited by $6 \% \mathrm{NaCl}$ solution after 24 hours incubation. Multidrug resistant isolates had displayed lower minimum inhibitory concentrations (MIC) compared to non-multidrug resistant isolates. The same study showed that $\mathrm{NaCl}$ exhibits a rapid and growth phase dependent bactericidal activity with $69 \%$. Biofilm forming, strongly adherent isolates getting inhibited by $3 \%$ or more of $\mathrm{NaCl}(15)$.

According to the results of the current study, types of antiseptics and disinfectants commonly used in healthcare settings in Sri Lanka can be considered as effective to control HAIs in hospitals. However, bactericidal activity of currently used concentration of hypertonic saline is not satisfied.

\section{Conclusion \& recommendations}

Currently using concentrations of isopropyl alcohols $(60 \%)$, povidone iodine $(10 \%)$, chlorhexidine gluconate $(4 \%)$, sodium hypochlorite $(0.1 \%$ and $1 \%$ ), peracetic acid (1.62\%) and mixture of 2aminoethanol, didecyldimethylammonium chloride, potassium carbonate and dodecylamine $(2.5 \%)$ showed $100 \%$ bactericidal activity. Further, all lower concentrations tested also showed $100 \%$ bactericidal activity. However, lower concentrations cannot be recommended to use in healthcare settings as the dynamics of microorganisms are expected to be different in vivo. Further evaluation of bactericidal activity against anaerobic bacteria and fungicidal activity of these chemicals is very important before lower concentrations are recommended for healthcare systems.

However, bactericidal activity of currently used concentration $(1.9 \%)$ of hypertonic saline is not satisfactory. It is noteworthy that higher concentration of hypertonic saline is more effective than already used concentration. However, this result too to be evaluated further considering other factors such as cytotoxicity of the compound.

\section{Limitations}

Although lesser concentrations of selected antiseptics and disinfectants other than hypertonic saline have shown similar bactericidal activities, those cannot be recommended for clinical use without further studies. There may be several other biological factors contributing to the bactericidal activity in vivo applications.

\section{Conflict of interest}

The authors disclose that there is no conflict of interest.

\section{References}

1. Aly NYA, Al-Mousa HH, El Sayed M. Nosocomial infections in a medical-surgical intensive care unit. Med Princ Pract.2008; 17(5): 373-7. DOI: 10.1159/000141500.

2. Kariyawasam N, Wong MC, Mahipala P, Turner P. Reducing Nosocomial Infections: A User-centered approach to developing an eHealth system for Sri Lankan ICUs. Stud Health Technol Inform. 2015; 208: 200-204.

3. Fernando M, Luke W, Miththinda J, Wickramasinghe R, Sebastiampillai BS, Gunathilake M, et al. Extended spectrum beta lactamase producing organisms causing urinary tract infections in Sri Lanka and their antibiotic susceptibility pattern - A hospital based cross sectional study. BMC Infect Dis. 2017; 17(1): 138. DOI: 10.1186/s12879-017-2250-y. 
4. Bowler PG, Duerden BI, Armstrong DG. Wound microbiology and associated approaches to wound management. Clin Microbiol Rev. 2001; 14(2): 244-269. DOI: 10.1128/CMR.14.2.244-269.2001.

5. Esposito S, Leone S, Noviello S, Fiore M, Ianniello F, Felaco FM, et al. Foot infections in diabetes (DFIs) in the out-patient setting: an Italian multicentre observational survey. Diabet Med. 2008; 25(8): 979-84. DOI: 10.1111/j.1464-5491.2008.02507.x.

6. Kumara DUA, Fernando SSN, Kottahachchi J, Dissanayake DMBT, Athukorala GIDDAD, Chandrasiri NS, et al. Evaluation of bactericidal effect of three antiseptics on bacteria isolated from wounds. $J$ Wound Care. 2015; 24(1): 5-10. DOI: 10.12968/jowc.2015.24.1.5.

7. Vianna ME, Gomes BPFA, Berber VB, Zaia AA, Ferraz CCR, de Souza-Filho FJ. In vitro evaluation of the antimicrobial activity of chlorhexidine and sodium hypochlorite. Oral Surgery, Oral Med Oral Pathol Oral Radiol Endodontology. 2004; 97(1): 79-84. DOI: 10.1016/s1079-2104(03)00360-3.

8. Sassone LM, Fidel RAS, Murad CF, Fidel SR, Hirata Jr R Antimicrobial activity of sodium hypochlorite and chlorhexidine by two different tests. Aust Endod J. 2008; 34(1): 19-24. DOI: 10.1111/j.1747-4477.2007.00071.x.

9. Bocian E, Grzybowska W, Tyski S. Evaluation of mycobactericidal activity of selected chemical disinfectants and antiseptics according to European standards. Med Sci Moni. 2014; 20: 666-673. DOI: 10.12659/MSM.890175.
10. Guentzel JL, Lam KL, Callan MA, Emmons SA, Dunham VL. Reduction of bacteria on spinach, lettuce, and surfaces in food service areas using neutral electrolyzed oxidizing water. Food Microbiology. 2008 Feb 1; 25(1): 36-41. DOI: 10.1016/j.fm.2007.08.003.

11. Sri Lanka College of Microbiologists. Hospital Infection control manual. R KKCPCEEJN V, editor. 2005. 180 p.

12. McDonnell G, Russell AD. Antiseptics and disinfectants: activity, action, and resistance. Clin Microbiol Rev. 2001; 14(1): 227.

13. Ekizoglu M. Evaluation of Bactericidal Activity of Certain Gluteraldehyde Free Disinfectants Used in the Disinfection of Endoscopes and Surgical Devices by a Quantitative Suspension Test. Hacettepe University Journal of the Faculty of Pharmacy. 2007; 27: 131-138.

14. Baldry MG. The bactericidal, fungicidal and sporicidal properties of hydrogen peroxide and peracetic acid. Journal of Applied Bacteriology. 1983 Jun; 54(3):417-23. DOI: $10.1111 / j .1365-2672.1983 . t b 02637 . x$.

15. Michon A-L, Jumas-Bilak E, Chiron R, Lamy B, Marchandin H. Advances toward the elucidation of hypertonic saline effects on Pseudomonas aeruginosa from cystic fibrosis patients. PLoS One. 2014; 9(2): e90164. DOI: 10.1371/journal.pone.0090164. 